\title{
Ihtiar Metodologis Nidhal Qassum Menuju Kalender Islam Internasional
}

\author{
Muh Rasywan Syarif \\ STAIN Watampone awan_elnaja@yahoo.co.id
}

\begin{abstract}
Abstrak
Nidlāl Qassūm adalah intelektual muslim abad 21 yang turut serta mengambil andil dalam konsep kalender hijriah internasional dengan berusaha memformulsikan awal dan akhir bulan kamariah berdasarkan visibiliats hilal. Ia menemukan bahwa dengan prinsip visibilitas hilal akan ditemukan ketidak sesuaian keterlihatan di berbagai negara terutama untuk negara yang berada di belahan Timur dunia. Konsep kalender Qassūm merupakan salah satu pemikiran kalender hijriah internasional yang menggunakan prinsip bizonal (membagi dunia menjadi dua zona). Zona Barat meliputi seluruh benua Amerika dan benua yang lain masuk dalam zona Timur. Dalam penentuan awal bulan, kalender Qassūm menggunakan kriteria hisab ijtimak qabla al-fajr di kota Makkah.
\end{abstract}

\section{Kata Kunci: Nidhal Qassūm, hisab, kalender internasional}

\section{Pendahuluan}

Pada dasarnya, sistem penanggalan atau kalender yang berkembang pada masyarakat terjadi dengan sendirinya melalui pengamatan terhadap pergerakan benda langit dan perubahan kondisi sekitar yang dilakukan dalam waktu yang sangat lama hingga dikenal sebagai siklus atau pola yang berulang. Siklus yang pertama kali diketahui adalah hari dari pengamatan siang dan malam, kemudian perubahan fase-fase bulan menjadi bulan dan pergantian musim. ${ }^{1}$ Kalender atau tanda-tanda penentuan waktu merupakan produk paradaban manusia dalam pengertian yang sederhana, apapun sebuah peradaban tetap membutuhkan kalender sebagai alat perhitungan

\footnotetext{
1 Ruswa Darsono, Penanggalan Islam: Tinjaun Sistem, Fiqih dan Hisab Penanggalan, (Yogyakarta: LABDA Press, 2009), hlm.29-30.
}

waktu yang tepat. Ketepatan perhitungan kalender sebagai perhitungan waktu, baik masa silam, sedang maupun waktu yang akan datang memberikan kepastian penggunaannya. Sejak peradaban awal dalam kehidupan manusia primitive sampai kepada kehidupan manusia modern. Kesemuannya mempunyai alat ukur waktu. Standarisasi awal waktu sejak awal peradaban manusia sampai sekarang sebenarnya terbagi empat standar sistem waktu yaitu :

1. Sistem waktu berdasarkan patokan Matahari atau lebih dikenal solar sistem atau popular juga disebut sebagai kalender sistem Matahari atau takwim Syamsiah seperti yag digunakan oleh kalender Masehi

2. Sistem waktu berdasarkan patokan bulan atau lebih dikenal dengan kalender sistem lunar atau popular 
disebut dengan kalender kamariah seperti kalender Islam Hijriah

3. Sistem waktu berdasarkan patokan bulan dan Matahari atau lebih dikenal dengan lunar solar atau popular disebut dengan kalender bulan Matahari seperti yang digunakan kalender Yahudi dan Cina

4. Sistem waktu berdasarkan patokan gejala alam atau fenomena alam yang menjadi dasar dalam penentuan waktu seperti halnya pasang surut air laut (hanya digunakan beberapa kelompok tertentu) pergantian musim dan lain sebagainya, sebagaimana yang di praktekkan oleh kaum primitive dan komunitas an-Nazir di Gowa. $^{1}$

Keempat standar sistem waktu itulah yang melatar belakangi metode penetapan waktu dengan berbagai formulasi dan kriteria. Dengan sistem tersebut lahirlah beberapa kalender baik yang bersifat lokal, nasional, regional, maupun international. Berdaarkan hasil penelitian macam-macam kalender ditemukan lebih 40 jenis yang sampai hari ini masih berlaku dan termasuk beberapa Negara mempergunakan lebih dari satu sistem kalender seperti halnya : Indonesia, india, dan beberapa Negara lainnya.

1 Sebuah kelompok (jamaah) bernama an-Nazir, di Gowa, Sulawesi Selatan, sebuah jamaah yang embrionya berasal dari aliran tarekat. Penetapan 1 Ramadhan mereka tempuh dengan melihat pasang surut air laut.
Secara garis besar ada dua kalender yang sangat berpengaruh dalam kehidupan pradaban modern ini adalah kalender yang beriorentasi kepentingan ekonomi, social, dan sipil dan kalender yang beriorentasi terhadap kepentingan agama khususnya dalam kalender Islam Internasional atau kalender hijriah Global sebagaimana kalender Masehi yang sudah melalui reformasi atau perubahan sedemikian rupa melalui berbagai kajian dan kebijkan politik sehingga dapat berlaku secara internasional.

Dari berbagai kajian ilmiah bahkan berskala internasional telah dilakukan berbagai seminar dibeberapa Negara dan setidaknya sudah 16 kali diadakan sejak tahun $1393 \mathrm{H} / 1973 \mathrm{M}$ hingga $1437 \mathrm{H} /$ 2016 M. dari berbagai pemikiran dan musyawarah cendekiawan Muslim astronomi Islam dengan merumuskan kriteria dari berbagai model kalender sistem Internasional. Diantara solusi dan tawaran konsep kalender Islam Internasional Nidhal Qassum.

\section{Biografi Nidhal Qassum}

Riwayat hidup seorang tokoh perlu didialogkan untuk melihat sejauh mana orisinalitas pemikiran tersebut mengalami dialektika atau proses pendidikan dengan pemikiran lainnya. ${ }^{2}$ Karena itu, pemikiran

2 Studi tokoh memungkinkan peneliti memandang sang tokoh dalam konteks seluruh kehidupannya, mulai dari kelahiran sampai kematiannya. Subyek studi dipandang sebagai orang yang mengalami keberhasilan dan kegagalan, dan memandang masa depan dengan harapan dan ketakutan. Ketokohan seseorang paling tidak dapat dilihat dari tiga indikator. Pertama, integritas tokoh. Hal ini dapat dilihat dari kedalaman ilmunya, 
Nidhal Qassum tidak akan bisa dipahami secara baik dan tepat tanpa melihat sejarah atau tradisi panjang yang melingkupinya. Dengan demikian, mengkaji sosio-biografi seorang tokoh dapat diketahui konteks pemikirannya.

Prof. Dr. Nidhal Qassum dan selanjutnya disebut Nidhal Qassum dilahirkan di Al-Jazair pada tanggal 6 September $1960^{1}$ dari keluarga pecinta ilmu. Ayahnya berhasil mendapatkan gelar doktor dalam bidang filsafat dari Universitas Kairo dan Sorbonne, Paris. Ibunya mendapatkan gelar master dalam bidang sastra Arab, sedangkan keempat saudaranya tumbuh menjadi ilmuwan, dokter, dan guru sains yang semuanya menjiwai rasionalisme filsafat, metodologi sains modern, keindahan seni dan sastra, serta keseluruhan pandangan dunia mengenai Islam. ${ }^{2}$

Sejak usia dini dan remaja dibesarkan dalam linkungan

kepemimpinannya, keberhasilan dalam bidang yang digeluti hingga mempunyai kekhasan atau kelebihan dibanding orangorang segenerasinya, dan juga dapat dilihat dari integritas moralnya. Kedua,, karya monumentalnya, baik karya tulis, karya nyata dalam bentuk fisik maupun nonfisik yang bermanfaat bagi masyarakat atau pemberdayaan manusia, baik di zamannya maupun sesudahnya. Ketiga, kontribusinya dalam masyarakat yang dapat dirasakan oleh masyarakat, baik dalam bentuk pemikiran maupun aplikasinya. Lihat selengkapnya Syahrin Harahap, Metodologi Studi Tokoh Pemikiran Islam, (Jakarta: Prenada Media Group, 2011), hlm. 7.

Diakses dari
http://en.wikipedia.org/wiki/Nidlāl_Qassūm
pada tanggal 23 Juli 2016 pukul 08:36
Wita. $\quad{ }^{2}$ Nidlāl Qassūm, Islam dan Sains
Modern, diterjemahkan oleh Maufur,
Bandung : Mizan, 2014, hal. 24.

pendidikan tradisi budaya Muslim dan gemar mempelajari segala bentuk ilm pengetahuan dan agama. Sejak awal Nidhal Qassum menempuh pendidikan dengan menguasai dua bahaa dunia yaitu bahasa arab dan bahasa Prancis. Semnatara bahasa inggris dipelajari pada masa remajanya. Pendidikan formalnya dibidang fisika sehingga tidak mengherankan jika beliautertarik dan terlibat penuh dalam berbagai penelitian atau riset astrofisika. Disamping itu Nidhal Qassum termasuk gemar membaca buku, baik filsafat maupun astronomi, khususnya yang berkaitan agama dan ilmu pengetahuan. ${ }^{3}$

Gelar sarjanaya di peroleh pada tahun 1982 di jurusan fisika teori University of Science and technology of Algiers, Aljazair. Dia kemudian hijrah ke Amerika untuk melanjutkan pendidikan pascasarjana. Gelar master sekaligus doktornya diperoleh dari universitas yang sama, yaitu Universitas California di San Diego. ${ }^{4}$ Disertasi doktoralnya yang berjudul "Thermonuclear Reactions of Light Nuclei in Astrophysical Plasmas" berhasil dia selesaikan pada tahun 1988. Setelah menyelesaikan program doktornya dia menjadi peneliti post-doktoral selama dua tahun di Goddard Space Flight Center NASA di bawah pengawasan Reueven Ramaty. Selain menjadi peneliti di NASA saat itu, dia juga banyak melakukan kunjungan dan melakukan

\footnotetext{
Sains...,hal. 25.

3 Nidlāl Qassūm, Islam dan

4 Nidlāl Qassūm, Short $C V$, diakses dari www.Nidlāl guessoum.org pada tanggal 23Juli 2016 pukul 09:51 Wita
} 
kolaborasi penelitian dengan beberapa institusi di Prancis. Selama beberapa tahun dia berkolaborasi dengan International Gamma-Ray Astrophisics Laboratory (INTEGRAL) pada Pusat Studi Radiasi Ruang Angkasa (Center for Space Radiation Studies) di Toullouse, Prancis. ${ }^{1}$

Karir kerjanya selanjutnya dihabiskan di negara asalnya, Aljazair. Selama lima tahun (1990-1995) dia bekerja di University of Blida, Aljazair. Setelah itu dia pindah ke Kuwait hingga tahun 2000 dan mengajar di College of Technological Studies. Semenjak tahun 2000 hingga sekarang Qassūm menjadi tenaga pengajar di American University of Syarjah, Uni Emirat Arab dan tercatat sebagai anggota International Astronomical Union (IAU), International Society for Science and Religion (ISSR), dan Islamic Crencents Observation Project (ICOP). ${ }^{2}$

Disamping

karir intelektualnya di Negara Aljazair juga telah menjadi staf mengajar dibeberapa kampus terkemuka di dunia, seperti Cambridge University, Oxford University, Cornell University dan Wisconsin University. Dia mengawali karir akademisnya dengan menjadi asisten professor sewaktu menyelesaikan program doktoralnya di University of California, San Diego. Dia menulis

\footnotetext{
${ }^{1}$ Nidlāl Qassūm, Visibility Of The Thin Lunar Crescent: The Sociology Of An Astronomical Problem (A Case Study), Journal of Astrnomical History and Heritage 4 (1), 2001, hal.14.

2 Diakses dari www.NidhalQassūm.org pada tanggal 23 Juli 2016 pukul 08:52 WITA.
}

lebih dari 100 artikel sains dengan beberapa bahasa diantaranya Arab, Inggris, dan Prancis. Di antara karyakaryanya dalam buku yang berkaitan dengan Islam dan sains adalah The Determination of Lunar Crescent Month and the Islamic Calendar (arabic), The Story of the Universe (arabic), Applications of Astronomical Calculations to Islamic Issues, Reconcilier l'Islam et la Science Modern : l'esprit d'Averroes, Islam's Quantum Question : Reconciling Muslim Tradition and Moslem Science, Astronomy for the Islamic Society (editor proceeding of the second emirates (international) astronomical conference) dan Kalam's Necessary Engagement with Modern Science. ${ }^{3}$

\section{Nidhal Qassum dan Gagasan Kalender Islam Internasional}

Gagasan terbentuknya kalender Islam Internasional sudah semenjak sesudah wafatnya Rasulullah saw. Sebab Rasulullah saw sebagai otoritas tunggal menentukan sistem waktu. kebutuhan mendesak ini baru terealisasi pada masa Khalifah Umar Bin Khattab yang menetapkan tanggal 1 Muharram sebagai awal tahun Islam yang kemudian dikenal sebagai tahun Hijriah. Perjalanan panjang selanjutnya dibutuhkan kalender Islam Hijriah Internasional.

Dari berbagai usaha merumuskan formulasi kalender Islam $^{4}$ internasional dapat

${ }^{3}$ Qassūm, Curriculum ..., hal. 910.

4 Semua Kalender Islam asasnya sama yaitu setiap bulannya bergantung pada siklus Bulan (Qamar). Menurut Susiknan Azhari diperlukan paradigma baru dalam 
dikategorikan secara garis besar dalam bentuk kalender Hijriah Internasional dengan berbagai kriteria tertentu, sebagaimana tabel berikut ini:

perumusan Kalender Hijriah atau kalender Islam. Paradigma baru yang dimaksud adalah kalender yang berdasarkan sistem kamariah dan awal bulannya dimulai apabila setelah terjadi ijtima Matahari tenggelam terlebih dahulu dibandingkan bulan (moonset after Sunset) pada saat itu posisi hilal di atas ufuk di suatu wilayah. Lihat Susiknan Azhari, Ilmu Falak: Perjumpaan Khazanah Islam dan Sains Modern, (Lihat h.78) cet.II, (Yogyakarta: Suara Muhammadiyah, 2007), hlm. 82 dan lihat juga Susiknan Azhari, Ensiklopedi Hisab Rukyat, Yogyakarta: Pustaka Pelajar, 2008, hlm. 118. 


\begin{tabular}{|c|c|c|c|}
\hline No & Model Kalender & Kriteria & Wilayah Keberlakuan \\
\hline 1. & $\begin{array}{c}\text { Kalender Mohammad } \\
\text { Ilyas }\end{array}$ & Visibilitas Hilal Ilyas & $\begin{array}{l}\text { Trizonal: zona Asia Pasifik, } \\
\text { Zona Eropa, Asia Barat, dan } \\
\text { Afrika, dan zona Amerika }\end{array}$ \\
\hline 2. & $\begin{array}{l}\text { Kalender Qasum, al- } \\
\text { ‘Atbi dan Mizyan }\end{array}$ & $\begin{array}{l}\text { Visibilitas Hilal } \\
\text { Schaefer }\end{array}$ & $\begin{array}{l}4 \text { zona: Pertama, } 180^{\circ} \text { BT- } \\
75^{\circ} \text { BT, Asia Selatan, Timur } \\
\text { dan Tenggara, Kedua, } 75^{\circ} \\
\text { BT- } 30^{\circ} \text { BT: Asia Kecil. } \\
\text { Ketiga, } 30^{\circ} \text { BT- } 1^{\circ} \text { BB: Afrika } \\
\text { dan Eropa, dan Keempat } 15^{\circ} \\
\text { BB- } 80^{\circ} \text { BB: Kawasan } \\
\text { Atlantik dan benua Amerika }\end{array}$ \\
\hline 3. & $\begin{array}{c}\text { Kalender Unifikasi } \\
\text { Jamaluddin Aburraziq }\end{array}$ & Visibilitas Hilal Odeh & Satu hari satu tanggal \\
\hline 4. & $\begin{array}{c}\text { Kalender Qassum- } \\
\text { Audah }\end{array}$ & $\begin{array}{l}\text { Konjungsi Sebelum } \\
\text { Fajar di Mekah dan } \\
\text { Visibilitas hilal Odeh }\end{array}$ & $\begin{array}{c}\text { Dwizonal: zona Barat terdiri } \\
\text { seluruh wilayah Amerika dan } \\
\text { zona Timur Selain Amerika }\end{array}$ \\
\hline 5. & $\begin{array}{c}\text { Kalender Ummul } \\
\text { Quro }\end{array}$ & Wujudul Hilal, Rukyah & - \\
\hline 6. & $\begin{array}{l}\text { Kalender Hijriah } \\
\text { Universal }\end{array}$ & Visibilitas Hilal Odeh & $\begin{array}{c}\text { Dwizonal: zona Barat terdiri } \\
\text { seluruh wilayah Amerika dan } \\
\text { zona Timur terdiri Eropa, } \\
\text { Afrika, Asia, Australia. }\end{array}$ \\
\hline
\end{tabular}

Tabel Formulasi Kalender Islam Internasional ${ }^{1}$

${ }^{1}$ Muh Nashirudin, Kalender Hijriah Universal: Kajian atas Sistem dan Prospeknya di Indonesia, Semarang : EL-WAFA, 2013, hal. 176 
Oleh karena itu, konsekuensi logis dari 6 usulan kalender Islam internasional tersebut tentu masih mensisahkan problem, setidaknya kalender mana yang tepat digunakan setiap Negara yang tepat dengan berbagai kriteria tertentu. Keresahan intelektual dan kebutuhan yang mendesak umat Islam agar melaksanakan hari ibadah secara bersama melalui pendekatan Syar'i maupun pendekatan astronomi Islam (Ilmu Falak).

Keprihatinan global ini demi menjaga persatuan umat Islam serta adanya keyakinan beribadah tepat waktu sebab beribadah tidak tepat waktu tentu dalam berbagai hal dapat dikatakan tidak sah. Sebab berbagai bentuk ibadah dilaksanakan sesuai ketepatan waktunya. Kondisional inilah yang salah satu melatarbelakangi diadakan seminar Internasional Islam yang secara khusus membahas tentang kalender Islam internasional bersama kriteriakriterainya. Berdasarkan seminar internasional temu pakar II pengkajian perumusan kalender Islam Internasional yang diadakan di Maroko pada tanggal 8-9 november 2006/ 18-19 syawal $1427 \mathrm{~h}$ yang merumuskan 6 syarat validitas kalender internasional yang ideal sebagai berikut:

1. Kalender Islam harus merupakan kalender yang dapat digunakan untuk kepentingan urusan duniawi dan urusan iabadah sekaligus

2. Kalender Islam harus didasarkan kepada bulan kamariah dimana durasinya tidak lebih dari 30 hari dan tidak kurang dari 29 hari
3. Kalender Islam harus merupakan kalender unifikatif, dalam arti satu hari satu tanggal di seluruh dunia

4. Kalender Islam tidak boleh menjadikan sekelompok orang Muslim di suatu tepat di muka Bumi memasuki bulan baru sebelum kelahiran hilalnya

5. Kalender Islam tidak boleh menjadikan sekelompok orang muslim di suatu tempat di muka Bumi mulai bulan baru sebelumnya yakni terjadinya imkanu rukyat hilal di suatu tempat di muka bumi

6. Kalender Islam tidak boleh menjadikan sekolompok orang muslim di suatu tempat di muka bumi belum memasuki bulan baru sementara hilal bulan tersebut telah terpampang secara jelas di ufuk mereka. ${ }^{1}$

Berdasarkan berbagai pertimbangan dari berbagai aspek terutama demi aspek syar'I, aspek astronomi dan aspek-aspek lainnya. Maka seminar merekomendasikan usulan 4 jenis kalender Islam internasional untuk diteliti lebih lanjut sebagai alternative kedepan yang dapat dijadikan kalender Islam Hijriah Internasional, yaitu:

1. Kalender Yallop

2. Kalender Libya

3. Kalender Umul Quro

4. Jamaluddin Abd Razik

1 Syamsul Anwar, Diskusi dan Korespondensi Kalender Hijrih Global, Yogyakarta: Suara Muhammadiyah, 2014, hal. 42. 
Terlepas dari hasil seminar internasional temu pakar II tentang pengkajian perumusan kalender Islam internasional yang tidak memasukkan Nidhal Qassum sebagai salah satu alternative menuju kalender Hijriah internasional, sebab menjadikan bizonal sehingga membuka kemudian masalah ada dua hari lebaran atau katakanlah terjadi bukan satu hari satu tanggal untuk satu dunia sebagaimana kemapanan kalender masehi. Akhirnya temu pakar II secara otomatis menolak semua bentuk kalender bizonal, trizonal, maupun empat zonal karena dianggap tidak menyelesaikan keseragaman ketepatan waktu. Namun demikian konsep Nidhal Qassum dengan kalender bizonal mempunyai keunggulan dari segi aspek syar'I sehingga sangat menarik untuk dikaji ulang karena memberikan kepastian kemungkinan pelaksanaan hari-hari ibadah berdasarkan pendekatan syar'I dan astronomi dengan konsep kalender Islam bizonal.

\section{Nidhal Qassum dengan konsep kalender Zonal}

Ketiadaan

kalender

komprehensif dan terunifikasi di kalangan umat Islam menyebabkan dunia Islam mengalami semacam kekacauan pengorganisasian waktu. Hal ini tampak sekali dalam kenyataan bahwa untuk hari raya Idulfitri atau Iduladha misalnya bisa terjadi perbedaan yang mencapai empat hari. Sebagai contoh Idulfitri tahun $1428 \mathrm{H}$ jatuh pada hari yang bervariasi di kalangan umat Islam sejak dari hari Kamis, Jum'at, Sabtu hingga Ahad. ${ }^{1}$

Sebagai seorang ahli astronomi Qassūm menyadari bahwa tampakan pertama hilal di atas bumi beberapa belas jam setelah ijtimak (konjungsi) sifatnya terbatas, dalam pengertian tidak senantiasa mencakup seluruh permukaan bumi. Artinya pada saat tampakan pertama hilal ada bagian Bumi yang dapat melihat hilal dan ada bagian muka Bumi yang tidak dapat melihat hilal pada hari yang sama. Bahkan kawasan yang terletak di atas (sebelah utara) garis Lintang utara 60 derajat dan kawasan di bawah (sebelah selatan) garis Lintang Selatan 60 derajat (kawasan yang tidak mengalami terbit dan terbenamnya Matahari dan Bulan untuk waktu yang lama) tidak dapat melihat hilal. Yang selalu mungkin melihat hilal adalah orang yang berada pada kawasan muka Bumi dalam jarak 60 derajat ke Utara dan 60 derajat ke Selatan dari khatulistiwa (ekuator Bumi). ${ }^{2}$

Pada hakekatnya jika merujuk kepada tujuan kalender sebagai ketepatan-samaan waktu tentu dapat dijadikan masalah. Tetapi bukanlah distu permasalahan intinya yaitu belum adanya kesepakatan kriteria penetapan dan belum adanya otoritas tunggal (pemerintah atau lembaga) yang menetapkan keeragaman kriteria tersebut untuk

1 Syamsul Anwar Anwar, Hari Raya dan Problematika Hisab Rukyat, Yogyakarta : Suara Muhammadiyah, 2008, hal. 115.

${ }^{2}$ Qassūm, et al., Itsbāt al-Syuhūr al-Hilāliyyah wa Musykilah al- Tauqīt alIslāmī, Beirut: Dar al-Thali'ah li al-Thiba'ah wa al-Nasyr, 1997, hal. 82. 
dipahami dan dijalankan bersama, tertuma pada hari-hari ibadah umat Islam. Konsep kalneder bizonal Nidhal Qassum memberikan solusi alternative berdasarkan konsep dua zona kebrlakuannya. Artinya konsep tersebut berperasn serta mengurangi perbedaan penentapan awal dan akhir bulan kamariah sekaligus memberikan kepaastian secara sistematis berdasarkan zonal melalui kriteria imkanu rukyat.

$$
\text { Menurut Qassūm }
$$

perkembangan perumusan kalender hijriah internasional mengarah kepada dua buah kesimpulan, yaitu kalender zonal dan kalender yang didasarkan pada syarat terjadinya ijtimak/iqtirān. Kalender zonal dipelopori oleh Mohammad Syaukat 'Audah dan Nidhal Qassūm sendiri, sedangkan kalender terpadu dipelopori oleh Jamaluddin Abdurraziq dan Khalid Syaukat dan Amerika. Namun, Qassūm menyadari bahwa untuk mewujudkan kesatuan penanggalan hijriah di seluruh dunia kalender yang didasarkan pada syarat terjadinya ijtimak terlihat lebih menjanjikan dari pada kalender zonal.

Adanya perbedaan zonal ini, selama masih tetap dalam ketentuan syar'I dengan memperhatikan zonazona tersebut. karena menurut Nidhal Qassum bahwa penyelesaian masalah perbedaan matlak harus memperhatikan dasar-dasar perhitungan astronomi dan geografi. Nidhal Qassum dengan konsep kalender bizonal memiliki keunggulan yaitu: Pertama, kesatuan matlak pada zona-zona yang tetap dan Kedua, bersatunya dunia Islam dalam melaksanakan awal bulan kamariah. Begitupun kelemahan dari konsep kalender bizonal Nidhal Qassum adalah adanya kemungkinan perbedaan dalam memulai awal bulan baru hijriah antara zona Barat dan zona Timur.

Kelebihan dan kekurangan kalender bizonal Nidhal Qassum jika dikaitkan dengan matlak atau wilayah keberlakuannya dapat diapahami sebagai keutamaan ketepatan syariah dari pada permasalahan satu hari satu tanggal di seluruh dunia, walaupun melalui pendekatan teknologi satelit bahkan menurut Thomas Djamaluddin sebelum teknologi satelit dipakai perlu kajian syariah yang mendalam berkaitan dengan matlak rukyatul hilal dari satelit. ${ }^{1}$ Tanpa definisi masalah matlak (zonal) hasil pengamatan hilal dari satelit belum menyelesaikan masalah logika astronomi. Maka dari itu astronomi tidak boleh mengabaikan syariat sebab kalender Islam internasional masih tetapmensisahkan juga persoalan lainnya. diantaranya, Nidhal Qassum sendiri mengabaikan kritik terhadap konsep kalender hijriah internasional yang ditawarkan oleh Jamaluddin Abdurraziq. Kalender hijriah terpadu usulan Jamaluddin Abdurraziq ini dikatakan sebagai sebuah proyek yang sangat ambisius karena menjadikan dunia dalam satu kesatuan penaggalan hijriah. Artinya, bulan baru kamariah akan mulai

\footnotetext{
$\begin{array}{lll}1 & \mathrm{~T} & \text { Djamaluddin } \\ & \text { (Peneliti }\end{array}$ LAPAN) "Logika Astronomi Tidak Boleh Abaikan Syariat" dalam buku Susiknan Azhari, Hisab dan Rukyat: Wacana untuk membangunkebersamaan di tengah perbedaan, Jogjakarta: Pustaka Pelajar,2007, hal. 156.
} 
dalam hari yang sama di seluruh dunia. Hanya saja, bulan baru hijriah sering dimulai padahal hilal mustahil untuk dirukyat (karena posisi hilal yang masih di bawah ufuk) di beberapa negara Islam, bahkan terkadang mustahil dirukyah di sebagian besar dunia Islam.

Di samping itu pada kajian lain, Nidhal Qassum juga melontarkan kritik tajam terhadap kriteria kalender hijriah unifikasi yang ditawarkan Jamaluddin untuk mengetahui kesesuaian kalender hijriah terpadu terhadap kemungkinan visibilitas hilal berdasarkan kriteria 'Audah. Qassūm memperoleh hasil yang mengejutkan, dia menyatakan bahwa untuk dunia Islam terdapat $58 \%$ kesesuaian awal bulan baru dalam kalender hijriah unifikasi Jamaluddin dengan kemungkinan visibilitas hilal, 10\% bulan baru dimulai dalam keadaan rukyat yang sulit dan $32 \%$ permulaan baru dimulai padahal hilal tidak mungkin di rukyat.

Qassūm memandang hingga saat ini terdapat dua konsep kalender penting yang didasarkan pada syarat terjadinya ijtimak, yaitu kalender Ummal-Qura dan kalender hijriah unifikasi yang digagas oleh Jamaluddin Abdurraziq. Kalender Umm al-Qura yang menggunakan kriteria terbaru dalam beberapa pertemuan ahli falak internasional diusulkan sebagai kalender hijriah internasional yang menggunakan kota Makkah sebagai marjaknya. Sedangkan kalender hijriah terpadu Jamaluddin Abdurraziq merupakan usulan terbaru dari kalender hijriah internasional yang berusaha menyesuaikan konsep hari dalam kalender Islam seperti kalender Masehi.

Dari sinilah Qassūm merumuskan kaedah baru mengenai kalender hijriah internasional yang secara implisit mengadopsi pemikiran perkembangan kalender hijriah internasional, yaitu kalender zonal dan kalender yang didasarkan pada syarat terjadinya ijtimak. Ada tiga rumusan dasar dalam kalender Qassūm` yaitu :

1. Dunia dibagi menjadi dua zona, yaitu benua Amerika di zona Barat, dan selain itu (benua Asia, Australia, Eropa dan Afrika) di zona Timur.

2. Bulan baru kamariah dalam kalender hijriah dimulai pada hari berikutnya untuk kedua zona apabila ijtimak terjadi sebelum fajar di kota Makkah.

3. Bulan baru kamariah dimulai pada hari berikutnya di zona Barat dan ditunda satu hari di zona Timur apabila ijtimak terjadi antara fajar di kota Makkah dan pukul 12:00 WU.

Dari rumusan kalender yang ditawarkannya, ada dua poin penting yang menjadi elemen dasar pembentukan konsep kalender ini, yaitu pembagian dunia menjadi dua zona dan penggunaan kota Makkah sebagai patokan waktu terjadinya ijtima' qabla al-fajri dalam pergantian awal bulan kamariah. 


\section{Kesimpulan}

Konsep kalender Islam bizonal Nidhal Qassum melalui pendekatan syar'I dapat saja membuka kemungkinan perbedaan memulai dan mengakhiri awal bulan. Namun pembagian zonal dalam kalender Nidhal Qassum memberikan kepastian dalam melaksanakan hari ibadah dan turut memperkecil perbedaan waktu berbagai Negara setidaknya menjadi dua zona. Oleh karena itu, Untuk menciptakan sebuah sistem kalender Islam yang diberlakukan secara internasional harus ada dialog yang berkesinambungan antara intelektual muslim-pakar sains modern (astronomi/falak, geografi, fisika, matematika) dan syariah (hadis, fikih, ushul fikih, dan lain-lain). Hal ini dikarenakan kalender Islam internasional merupakan kalender yang dibangun sesuai dalil-dalil syar'i dan ilmu pengetahuan alam, khususnya yang berkaitan dengan Bumi, Matahari, dan Bulan. Untuk menciptakan sebuah sistem kalender Islam internasional yang didasarkan pada ketampakan hilal atau kriteria visibilitas hilal harus ada intervensi secara politis sebagai pemegang otoritas atas keberlakuannya.[]

\section{Daftar Pustaka}

Muh Nashirudin, Kalender Hijriah Universal: Kajian atas Sistem dan Prospeknya di Indonesia, Semarang : ELWAFA, 2013

Nidlāl Qassūm, Islam dan Sains Modern, diterjemahkan
olehMaufur, Bandung : Mizan, 2014

Nidlāl Qassūm, Visibility Of The Thin Lunar Crescent: The Sociology of An Astronomical Problem (A Case Study), Journal of Astrnomical History and Heritage 4 (1), 2001

Qassūm, et al., Itsbāt al-Syuhūr alHilāliyyah wa Musykilah alTauqīt al-Islāmī, Beirut: Dar alThali'ah li al-Thiba'ah wa alNasyr, 1997

Ruswa Darsono, Penanggalan Islam: Tinjaun Sistem, Fiqih dan Hisab Penanggalan, (Yogyakarta: LABDA Press, 2009).

Susiknan Azhari, Ensiklopedi Hisab Rukyat, Yogyakarta: Pustaka Pelajar, 2008

Susiknan Azhari, Hisab dan Rukyat: Wacana untuk membangun kebersamaan di tengah perbedaan, Jogjakarta: Pustaka Pelajar,2007

Susiknan Azhari, Ilmu Falak: Perjumpaan Khazanah Islam dan Sains Modern, (Yogyakarta: Suara Muhammadiyah, 2007)

Syahrin Harahap, Metodologi Studi Tokoh Pemikiran Islam, (Jakarta: Prenada Media Group, 2011

Syamsul Anwar Anwar, Hari Raya dan Problematika Hisab Rukyat, Yogyakarta : Suara Muhammadiyah, 2008

Syamsul Anwar, Diskusi dan Korespondensi Kalender Hijrih Global, Yogyakarta: Suara Muhammadiyah, 2014

\section{Link:}

http://en.wikipedia.org/wiki/Ni dlāl_Qassūm www.NidhalQassūm.org 
Short Curiculum Vitae, diakses dari www.Nidlāl

guessoum.org 
